\title{
TTR
}

Traduction, terminologie, rédaction

\section{When a Translator Joins the Revolution: A Paratextual Analysis of Manuel García de Sena's La independencia}

\section{Gabriel González Núñez}

Volume 27, numéro 1, 1er semestre 2014

Lecture et traduction

Reading and Translation

URI : https://id.erudit.org/iderudit/1037123ar

DOI : https://doi.org/10.7202/1037123ar

Aller au sommaire du numéro

Éditeur(s)

Association canadienne de traductologie

ISSN

0835-8443 (imprimé)

1708-2188 (numérique)

Découvrir la revue

Citer cet article

Núñez, G. G. (2014). When a Translator Joins the Revolution: A Paratextual Analysis of Manuel García de Sena's La independencia. TTR, 27(1), 189-211. https://doi.org/10.7202/1037123ar

\section{Résumé de l'article}

Au cours de la période complexe entourant l'indépendance latino-américaine, l'émergence de nouveaux États s'est accompagnée de la mise en oeuvre de nouvelles idées. Certaines de ces idées ont été en partie véhiculées grâce aux efforts de traducteurs séjournant aux États-Unis, parmi lesquels Manuel García de Sena, un traducteur vénézuélien qui publia des traductions de textes nord-américains. Les traductions de García de Sena sont rapidement diffusées, et l'une d'entre elles, en particulier, favorisera l'exportation vers les nouvelles républiques de mesures législatives venues des États-Unis. Les détails relatifs à la publication de cette traduction ont fini par se perdre. Cependant, l'apparail paratextuel de cette traduction recèle de précieuses informations sur le contexte historique et idéologique dans lequel la traduction a été réalisée et diffusée. L'analyse du titre, des dédicaces et des notes de cette traduction met en lumière le fait que celle-ci avait aussi pour fonction d'introduire un changement dans le répertoire culturel. En somme, le paratexte de cette traduction permet de découvrir le rôle joué par García de Sena dans la révolution. 


\title{
When a Translator Joins the Revolution: A Paratextual Analysis of Manuel García de Sena's La independencia ${ }^{1}$
}

\author{
Gabriel González Núñez \\ Universitat Rovira I Virgili \\ The University of Texas Rio Grande Valley
}

\begin{abstract}
During the complex period of Latin American independence, new states began to emerge and new ideas were implemented. Some of these ideas were made available in part due to the efforts of translators in the United States. Among them was Manuel García de Sena, a Venezuelan translator who published translations of North American texts. His translations enjoyed a prompt distribution. One of them became a vehicle that facilitated legal transplants from the United States to the new republics. While much has been lost to history regarding the details of the printing of this translation, its paratextual apparatus provides insights that help modern readers understand some things regarding the people involved, their ideas, and the times they lived in. By analyzing the title, the dedications, and the notes, we can see the translation's intended function in changing the culture repertoire. In essence, the paratext allows us to see what this translator did as he joined the revolution.
\end{abstract}

Keywords: paratext, culture planning, repertoire, constitution, García de Sena

\section{Résumé}

$\mathrm{Au}$ cours de la période complexe, entourant l'indépendance latinoaméricaine, l'émergence de nouveaux États s'est accompagnée de la mise en œuvre de nouvelles idées. Certaines de ces idées ont été en partie véhiculées grâce aux efforts de traducteurs séjournant aux États-Unis, parmi lesquels Manuel García de Sena, un traducteur vénézuélien qui publia des traductions de textes nord-américains. Les traductions de García de Sena sont rapidement diffusées, et l'une d'entre elles, en particulier, favorisera l'exportation vers les nouvelles républiques de mesures législatives venues

1. The author wishes to thank Anthony Pym and the peer reviewers for their input in the writing of this article. 
des États-Unis. Les détails relatifs à la publication de cette traduction ont fini par se perdre. Cependant, l'apparail paratextuel de cette traduction recèle de précieuses informations sur le contexte historique et idéologique dans lequel la traduction a été réalisée et diffusée. L'analyse du titre, des dédicaces et des notes de cette traduction met en lumière le fait que celleci avait aussi pour fonction d'introduire un changement dans le répertoire culturel. En somme, le paratexte de cette traduction permet de découvrir le rôle joué par García de Sena dans la révolution.

Mots-clés: paratexte, planification culturelle, répertoire, constitution, García de Sena

\section{Introduction}

In the early $19^{\text {th }}$ century, the revolts and insurrections against the Spanish crown that dated back to as early as 1749 came to full fruition in the wars of independence (Bastin and Iturriza, 2008 , p. 82). In the midst of the crumbling empire, new states began to emerge. They struggled from within over issues such as whether to adopt monarchical models or the more modern and largely untried democratic models operative in North America ${ }^{2}$ both at the state and federal level. Enlightenment ideas took hold to varying degrees in different places. Some of these ideas were made available in part due to the efforts of many a translator in the United States, including notable figures like Francisco de

2. There is some controversy as to whether the North American or the French models were more influential on Latin American Independence (Bastin and Echeverri, 2004, p. 572). Tanzi cites several authors in arguing that the ideas found in the French encyclopedism had no effect in Latin America's independence movements, and he makes a similar argument about the U.S. revolution; however, he concedes that when it comes to structuring the new Latin American states, the North American models were very influential (1979, pp. 45-61). However, there is much evidence pointing to the importation through translation of influential French and English texts leading up to the wars of independence and even during emancipation. These texts included works by Jean-Jacques Rousseau, John Locke, Montesquieu, and Voltaire (Bastin and Echeverri, 2004, p. 564). It seems apparent that Enlightment ideas, from thinkers in Europe and North America, did circulate throughout Spanish America. Both contributed to some degree, but there seems to be an "influence prédominante des textes nord-américains" during the struggles for independence and the creation of the new states (ibid., p. 572). 
Miranda 3 (De la Guardia, 2010, pp. 1-2).

Among them was Manuel García de Sena, a Venezuelan translator who published two major translations of texts from the United States. ${ }^{4}$ The first of those two translations was printed in Philadelphia, possibly between July 9 and August 18, 1811 (Grases and Harkness, 1953, pp.32-33). It had a rather long title-which we will abbreviate as $L a$ independencia - and was a translation of different writings by Thomas Paine plus a number of legal documents. By modern standards, it was a large tome: 288 printed pages, each 29 centimeters long (ibid., p. 33). It would play an important role in the events that were shaping part of the world (Tanzi, 1979, pp. 60-61).

The publication of this translation by García de Sena in 1811 serves as a case study of how translators can play an important role during revolutionary periods. Specifically, this paper aims to explore how translation can be an effective means of helping foster political change. The paper will attempt to explain, through García de Sena's case, some of the strategies translators have adopted in order to effectively transfer the ideas they want to see embraced. Bastin and Echeverri (2004) have considered García de Sena's strategies and reception alongside those of other translators. Bastin further claims that in northern South America's independence movements, translation was "un pretexto para obras mayores o distintas en las que la traducción solo es un ingrediente" [an excuse for larger or different work in which translation is only a part $]^{5}$ (2004, p. 11). This paper will build on that by taking a detailed look at the paratextual apparatus surrounding La independencia and linking it to notions of transfer in culture repertoire (EvenZohar, 2005).

One way to show how specific translators hope to achieve change through their translations is to simply ask them. Since

3. Francisco de Miranda was a key player in the independence of what he called the "continente colombiano," or Columbian continent. For a biography that stresses his activities and influence on both sides of the Atlantic, see Racine (2002).

4. His second work, Historia concisa de los Estados Unidos desde el descubrimiento de la América hasta el año de 1807, was a translation of John $\mathrm{McCulloch}$ 's history of the United States which was published shortly after La independencia (Grases and Harkness, 1953, p. 31).

5. All translations are my own. 
García de Sena has been dead for well over a century, ${ }^{6}$ other options must be sought, such as the translator's paratextual apparatus. A translation's paratext allows the researcher to contextualize translational phenomena (Tahir-Gürçağlar, 2002, pp. 58-59). The importance of paratexts when considering García de Sena's work has also been stressed by Bastin (2010). Of course, there are limitations to paratextual analyses, but at the very least the paratexts can provide an idea of how the translator wanted his or her work to be perceived. By analyzing the title, the dedications, and the notes, we can take a glimpse into the book's intended function. This will allow us to consider not only the translator's strategies, but also how he joined the revolution, not as a soldier but as a translator.

Of course, when dealing with any paratext, reference must be made to theorist Gérard Genette and the ideas in his seminal work Paratexts. In it, Genette defines the paratext as the texts that surround a work in a way that it can be presented as a book; these texts are "a threshold, or [...] a 'vestibule' that offers the world at large the possibility of either stepping inside or turning back" (Genette, 1997, pp. 1-2; italics in the original). He then takes each of the elements that create the paratext and dissects them with dispassionate discipline. In examining this translation's paratextual apparatus, we will compare Genette's observations about paratexts with García de Sena's paratextual apparatus to gain insights that may help us infer the translator's strategies.

In order to make sense of the insights, we need to place them in the context of theorist Itamar Even-Zohar's ideas regarding culture, as collected in Papers in Culture Research. For our current purposes, the crucial elements of Even-Zohar's culture theory have to do with how a culture repertoire is made and the role transfer plays in its making. A culture repertoire is to be understood as "the aggregate of options utilized by a group of people, and by the individual members of the group," the group ranging from a small family to an entire nation (Even-Zohar, 2005, p. 69). Group members are constantly making this repertoire, and at times they even engage in deliberate planning of the new repertoire (ibid.,

6. All we know about García de Sena's death is that it was before 1838 (Grases and Harkness, 1953, p. 27). For a very brief biographical sketch of García de Sena, focusing on his role in the revolutionary movement, see Bastin and Echeverri (2004, p. 565). 
pp. 70 and 77-78). One way of introducing new options into the repertoire is through importation into the group's market (ibid., p. 71). Not every option imported as a potential part of the repertoire actually makes it into the repertoire (ibid., pp. 71 and 91). When an option is successfully integrated, however, transfer has taken place (ibid.,p. 71). A successful act of transfer may occur, for example, when a translation manages "to make the semiotic models of these texts integral parts of the home repertoire" (ibid., p. 72; italics in the original). This article relies on Even-Zohar's theory to make sense of the translation's paratext. We will now proceed to analyze the translation's paratextual elements and try to make sense of them in the context of cultural transfer.

\section{The Title}

According to Genette (1997,pp. 56-57), a title can be composed of up to three elements: title, subtitle, and genre indicator. Whatever its composition, the title of a work may serve three functions: to designate, to tempt the public, and to describe the subject matter (ibid., pp.76-77). Genette (ibid., p. 76) sees designation (or identification) of the book as the title's only obligatory function. As for tempting the public to read the book, he finds this function of the title "so obvious and so elusive that it hardly prompts [him] to comment" (ibid., p. 91). Regarding description, he argues titles are either thematic or rhematic. Thematic titles are those that "bear on the "subject matter" (ibid., p. 81), while rhematic titles generally describe the genre or form of the book (ibid., pp. 86-87). He further claims there are "mixed titles" which have thematic and rhematic elements (ibid., p. 88).

The title of the book analyzed in the present study is either a thematic title or a mixed title. To reach that conclusion, we must first identify the title and then the thematic or rhematic elements.

So what is the title, exactly? When glancing at the book's title page, there is a great deal of information, as was customary at the time. The title is not easily discernible at first glance. Certainly the fonts are of no help, as every one of the 11 lines in the title page is formatted with a different font. One of the lines is even italicized, perhaps arbitrarily. Based on the title page, the book's title could be: La independencia de la Costa Firme justificada por Thomas Paine treinta años há [The Independence of Costa Firme as Justified by Thomas Paine Thirty Years Ago]. It could also be: $L a$ 
independencia de la Costa Firme justificada por Thomas Paine treinta años há. Extracto de sus obras traducido del ingles al español por D. Manuel Garcia de Sena ${ }^{7}$ [The Independence of Costa Firme as Justified by Thomas Paine Thirty Years Ago. An Extract from his Works Translated from the English into Spanish by Mr. Manuel García de Sena]. Which is it?

There are no definitive pronouncements from the publisher, from García de Sena, or from Paine on this subject. People seem to prefer the shorter title. The shorter title is easily justified by a close look at the title page. In it, a period will be noticed after the word $b a \hat{~}[a g o]$. At the very least, that is where the publishers of a 1949 printing of the book ${ }^{8}$ drew the line, as evidenced by the cover's more modern layout in which those thirteen words are the title, nothing else. Ironically, the longer title is the one used by historian Grases, who wrote the foreword to that same 1949 printing $(1949$, p. 8). In a later work, Grases uses the longer title once, and every time thereafter, he uses his own abbreviated versions: $L a$ independencia de la Costa Firme or simply La independencia (e.g., Grases and Harkness, 1953, pp. 32-49). In terms of convenience, there are obvious advantages to using the shorter title. During the translator's life, at least two high-profile individuals-José de Asturia and José Félix Blanco-used the shorter title (Grases, 1949, p.11-12). The shorter title is also preferred in modern cyberspace, where a search for the shorter title yields some 1,550 results, while a similar search for the longer title yields only four results.

What the title is becomes important when trying to analyze the descriptive function of the book's title. If we adopt the shorter title, the title seems to be thematic: This book's theme is the independence of Costa Firme ${ }^{9}$ as justified by Thomas Paine. If so, the title is deliberately misleading. Thomas Paine was not

7. In quoting $L a$ Independencia, this paper respects the orthographical choices of the 1811 book.

8. There are two editions of La independencia. The first edition was published in 1811. The second edition is a 1949 reprint of the first edition, printed in Caracas by the Instituto Panamericano de Geografía e Historia with an introduction by Grases (see Grases, 1949).

9. Costa Firme, also known as Tierra Firme, was an administrative jurisdiction of the Spanish empire. It included parts of what today is Colombia, Venezuela, and Panama. 
really concerned about Costa Firme and never wrote a book to justify its independence. His writings were not intended for the Spanish colonies or their emerging republics, either in general or specifically in Costa Firme. Perhaps García de Sena was eager to tempt the public with his title. Or perhaps there was some symbolic value to it, a thematic possibility according to Genette (1997, pp. 82-84). If so, the translator would be employing it not just to tempt the public but rather to inform the book's reader that the ideas presented by Paine are applicable to Spanish America. In other words, the title indicates the translator is transferring ideas from one culture to another.

If we adopt the longer title, the misleading element becomes diluted because rhematic elements are introduced which make for a clearer description of the book. This is true whether we wish to interpret the longer title as a single title or as the shorter title followed by a subtitle. The rhematic elements are introduced when the book is identified as a translation of selected works by Paine. By choosing a title that defines the book as a translation, the translator presents himself as "a reporter who simulates, reenacts, reproduces the reported discourse [here, the writings of Paine] mimetically" (Hermans, 2007, pp. 74-75). This conveys to the reader the idea that the translator is quoting another. Such conveying helps the public understand that this is not a book written by Paine to justify the independence of Costa Firme but a translated collection of works which result in the justification of such independence. We will later see this interpretation of the title is confirmed by the translator's dedicatory letters.

The title is misleading in another aspect, however. It omits any mention of the texts that comprise nearly half of the book. Of the 288 pages, the translation of Paine's works takes up 147 pages, the translation of the U.S. Declaration of Independence takes up 7 pages, and the translation of several U.S. state and federal constitutions takes up 114 pages. The inclusion of the constitutions is not hinted at in the title.

This omission can be interpreted in at least two ways. The first possibility is that the translator saw them simply as an appendix of sorts, a helpful afterthought. This is highly unlikely given that they take up so many pages. We could speculate that translating the constitutions took nearly as much time as translating the works of Paine. This makes it hard to believe that 
they were simply an afterthought, or some helpful information that was not central to the book's purpose. The second possibility is that the translator chose to omit mentioning them in the title in order to better tempt the public. If this is the case, the translator probably considered that the best way to get his intended public to read the book was by exploiting the potential reader's desire for independence from Spain. At least it seems that the desire for independence in Spanish America was greater than any consensus as to what form the emancipated state or states should take. This political reality may be reflected in the title, which mentions only independence and not the creation of new states.

Whatever title readers prefer, it reveals a few things about the translator and his time. The first is that he believed that there were important similarities between British America and Spanish America. More significantly, he believed that there were ideas in the United States that were applicable to Spanish America. Thus, the title reveals the translator as a facilitator for the flow of ideas from an early North American thinker to Latin American revolutionaries.

In other words, García de Sena saw translation as a means to devise new options in the culture planning which was taking place in his native land. This makes sense when we consider EvenZohar's (2005, pp. 77-78) explanation of culture planning as what occurs when individuals or groups begin negotiating between alternatives in the market. This was going on in Spanish America at the time when García de Sena engaged in his translation activities. It was clear that with the overthrow of the Spanish, a new repertoire would have to be devised, at least in the political arena. As the title implies, García de Sena saw translation as a way to enter the market at a time when the existing repertoire of Costa Firme was undergoing dramatic political changes.

The ideas found in La independencia were exported by García de Sena, who was a Spanish American that at the time lived in the United States. This is evidenced by the title page to $L a$ independencia, which reads in part: "Philadelphia. En la imprenta de T. y J. Palmer. 1811." Because of that inscription, the printer has been identified erroneously by some scholars as "T.J. Palmer" (Bernstein, 1951, p. 127) or "T.y J. Palmer" (Grases and Harkness, 1953, p. 33). The book was in reality published by Thomas and George Palmer, early American printers based in Philadelphia. 
Apparently, García de Sena chose to translate the printer's name. Thus, "Thomas and George Palmer" became "Tomás y Jorge Palmer," abbreviated as "T. y J. Palmer."

\section{The Prefatorial Writings}

Our initial impressions are confirmed in the letters that act as prefaces to La independencia. To better understand the nature and function of these letters, Genette's work on paratexts is helpful again. He explains that starting in the early nineteenth century, "the dedicatory epistle barely hangs on except by its prefacing function" (Genette, 1997, p. 125). That prefacing function includes "[...] the proclamation (sincere or not) of a relationship (of one kind or another) between the author and some person, group, or entity" (ibid., p. 135). Even though Genette generally assumes that the book's author is the dedicator, he recognizes that "some translations are dedicated by the translator" (ibid., p. 130). Such is the case of La independencia.

The book is prefaced by two letters. This begs the question as to whether the book actually has two dedications. Grases and Harkness (1953, p. 33) see the work as having a double dedication. Genette would probably disagree. He distinguishes between "[...] dedicatory epistles with a prefacing function and some letters of accompaniment that fulfill the same function without amounting to a dedication" (Genette, 1997, p. 125). In La independencia, the first letter is addressed simply to "RAMÓN" and the second to "los Habitantes de la Costa Firme" [the Inhabitants of Costa Firme]. The first is structured like a personal letter and reads like one. The latter is structured like a dedication proper, with this clearcut heading: "DEDICADA" [DEDICATED]. Consequently, it makes sense to think of La independencia as being prefaced by a letter of accompaniment and a dedication.

The letter of accompaniment is dated 15 December 1810 at Philadelphia. This suggests that the translating may have been finished as early as December 1810. If not, it surely was finished by 9 July 1811 , when a district clerk granted copyright protection to García de Sena for La independencia. As stated earlier, the letter of accompaniment is addressed to one Ramón. Ramón García de Sena was one of the translator's siblings (Grases and Harkness, 1953 , p. 13). He was a colonel who eventually would lose his life in the defeat of the Venezuelan forces at the battle of La Puerta on 15 July 1814 (Esteves González, 2007, pp. 77-78). 
The contents of the letter are specific instructions to Ramón. Yet by reading the letter, it becomes clear that the letter has a prefatorial function that goes beyond a private request made public. As will be seen below, this prefatorial letter turns Ramón into a double representative: he is to represent the translator before the government at Caracas, and he is to represent the reader as addressee of the letter.

The letter begins with an apology. The translator had entrusted the distribution of the book to someone other than Ramón. Something went wrong and now the translator acknowledges that he should have given this charge to Ramón from the beginning. The translator then asks Ramón to take copies of the book to Caracas' Junta Suprema Conservadora de los Derechos de Fernando VII (Junta Suprema). ${ }^{10}$ Specifically, the translator wants his brother to have the Junta Suprema approve the book for distribution among his fellow citizens.

This step Ramón is to take is important, because institutional rejection of the translation could have hampered the translation's distribution. We assume that Manuel García de Sena had invested a great deal of time-and perhaps money-in translating and printing the book with which he entrusted his brother. As is revealed through the prefatorial letters, the translator believed strongly that the ideas expounded by Paine and implemented in North America through constitutions were very promising for those fighting to become independent from Spain. If the government in power were to ban the book, the translator's efforts could have been for naught. More importantly, his hopes for change would have been dashed from the start.

In other words, García de Sena understood, at least intuitively, that his translations could introduce new options into

10. The Junta Suprema was a government created in Caracas that did not recognize the authority of King Joseph I in Spain. After Napoleon invaded the Iberian peninsula, he placed his brother (Joseph Bonaparte) in the Spanish throne. The Junta Suprema rejected the new Spanish regime and gathered support from several provinces to fight against Spain. This was done in the name of Ferdinand VII, the king that Napoleon had removed. In reality, the Junta Suprema overthrew the Spanish authorities and convened a Constitutional Congress, thus creating Venezuela's First Republic. For a brief recounting of the Junta Suprema and its role in the wars of independence, see Rodríguez O. (1998, pp. 110-116). 
the market, but their integration into the repertoire depended on those in power. Historically, people in power have engaged in culture planning, and with a few exceptions, those not in power have not participated (Even-Zohar, 2005, p. 80). In the early $18^{\text {th }}$ century, in order for a new option to enter the repertoire, those in power had to endorse it (ibid., p. 87). Thus, the prefatorial letter to Ramón was an attempt to make García de Sena's translation a viable option through the backing of those in power, in this case, the Junta Suprema.

Ramón was further instructed to tell the people the following: (1) that the writings translated in the book reveal truths the Spanish had attempted to conceal; (2) that the author was an Englishman who was the first in America to publicly denounce oppression and who spelled out rules for becoming and staying free of tyrants; and (3) that the people should not focus on the quality of the translation but rather on the principles exposed therein. The latter point relates back to the title page, where the book is defined as a translation. In this letter of accompaniment, García de Sena stresses that what matters is the content that is being reported through the translation; he wants to make sure that people think "Let's see what Paine has to say," as opposed to "Let's see how García de Sena translates" (see Pym, 2010, p. 62).

These instructions are followed by commentary on how the constitutions found in the book are examples of the best ways to put those principles in practice. The ultimate addressee of prefatorial comments is the reader (Genette, 1997, p. 194), who is here represented through Ramón. What García de Sena is doing through these prefatorial comments is indicating to the reader that the old, Spanish repertoire is oppressive and worthy of overthrow.

Generally speaking, there are many possible prefatorial functions to a book's introductory texts. Some of them become manifest in this letter of accompaniment. One possible prefatorial function is to insist on the novelty of the work (ibid., p. 200). By claiming that the ideas in La independencia were concealed by the former government of the Spanish colonies, García de Sena is in essence claiming that his readers will find the work novel. This serves to tempt the public to read the translation.

By claiming that it was Paine who introduced these novel ideas, the translator prefaces the book in a way that seems to deflect responsibility for the content from himself to someone else, 
namely, "the author." We are not claiming here that the translator did not want to be associated with Paine's ideas at all. Had the translator not wanted to be associated with the translation, he could have drafted an anonymous translation. Instead, he put his name on the book's title page, and he included two signed prefatorial letters. The translator's name thus became forever linked to the book. Nonetheless, he apparently did want to draw a line between Paine and himself; as we will see, however, that line is not always clearly visible.

In certain collections, such as La independencia, a prefatorial function may be to show the unity of the texts in the book (ibid., p. 201). Writing on this topic, Genette claims:

The genre that most insistently calls for a unifying preface is no doubt the collection of essays or studies, because this kind of collection is often most conspicuous for the diversity of its components and at the same time most anxious $[\ldots]$ to deny or compensate for that diversity. (ibid., pp. 202-203)

This observation applies to the letter of accompaniment, which serves to place Paine's writings under the umbrella of writings on principles useful for overcoming tyranny and keeping it at bay. The letter specifically cites the constitutions as models for the implementation of those principles. In a handful of paragraphs, this letter fuses all the translated texts into a coherent whole.

The letter of accompaniment is followed by a two-paragraph dedication. The dedication is addressed to the "Americanos Españoles" [Spanish Americans]. The phrase echoes the wording used by the aforementioned Miranda in translating a revolutionary letter by Juan Pablo Viscardo from French to Spanish ${ }^{11}$ (Bastin, 2010 , p. 52). In the dedication, the translator acknowledges that the desire for independence already existed among his readers. Such a desire was not imposed from abroad but rather homegrown (Tanzi, 1979, p. 60). The translator's dedication explains that he is simply offering a justification for those feelings. Nearly half of the dedication deals with his intended readers in Puerto Rico, encouraging them to press on. Puerto Rico was at the time

11. For more information on the Viscardo letter and its translation by Miranda, see Bastin and Castrillón (2004). For more information on Miranda's role as a forerunner of revolutionary translators, see Bastin (2006). 
the place to which the Spanish regency had been relegated and from which it continued to demand loyalty to the crown (Grases and Harkness, 1953, p. 36).

The dedication also reflects Garcia de Sena's simple understanding that the successful integration of his option in the repertoire depended on the degree to which the new option was more palatable than the former. In order to convince individuals to accept the new option, "propagators often refer to matters such as discrimination or humiliation which, it is then claimed, can be cured only if a current repertoire is overthrown" (Even-Zohar, 2005 , p. 90). This is exactly what the translator does through the letter, by first setting the readers at ease that what he has to offer is congruent with the change they want, and then by pointing out that this alternative offered by Paine and the constitutions is better than Spanish oppression. As stated earlier, the idea that the Spanish repertoire is oppressive and must be replaced is also present in the letter of accompaniment.

There are several common themes between the letter of accompaniment and the dedication. We can consider both of them a preface of sorts, if by preface we understand "[...] every type of introductory $[\ldots]$ text $[\ldots]$ consisting of a discourse produced on the subject of the text that follows [...] it" (Genette, 1997, p. 161). One of the main purposes of such introductory texts is to state the author's intent (ibid., p. 221) or, in this case, the translator's intent. The intent that seems to reveal itself is two-fold: (1) to offer a justification for independence from Spain, and (2) to offer examples of what the new government(s) should look like in practice.

Another theme that appears in the prefatorial writings is that there were good political ideas in North America that, if accepted in Spanish America, would lead to freedom and prosperity. García de Sena did not look to Europe or to Haiti to justify Costa Firme's independence and to offer examples of what shape the new government should take. He believed the proper place to look for those things was the United States. He publicly admired the happiness, freedom, and prosperity he witnessed firsthand in America's only republic. In the letter of accompaniment, he describes the government of the United States as "acaso el mas bello que ha existido jamas sobre la tierra" [perhaps the most beautiful that has ever existed upon the earth]. He did not seem 
to feel that there was anything inherent in the North Americans he met that led to their "felicidad" [happiness]; rather, it was the principles of independence and constitutional government that created the "tranquilidad y buen orden" [peacefulness and proper order] the translator witnessed in Philadelphia. He wanted that for his own people back home. As the dedicatory letter attests, translation was viewed as a legitimate means to help achieve those ends.

\section{The Notes}

The translation of the works of Paine begins after the two prefatorial writings by García de Sena and a table of contents. The table of contents lists the writings of Paine, the U.S. Declaration of Independence, and the following constitutions: the Articles of Confederation, the U.S. Constitution, the state constitutions of Massachusetts, New Jersey, Pennsylvania, and Virginia, and a description of the government of Connecticut. ${ }^{12}$ The writings of Paine come from Common Sense, Dissertation on the First Principles of Government, and Dissertations on Government, the Affairs of the Bank, and Paper Money. Out of Common Sense, the translator selected for translation the first two sections: "Of the Origin and Design of Government in general; with concise Remarks on the English Constitution" and "Of Monarchy and hereditary Succession." The Dissertation on the First Principles of Government and Dissertations on Government, the Affairs of the Bank, and Paper Money are translated whole.

There is a paratextual mechanism linked specifically to the translations of Paine's writings, namely the notes. By notes, we mean statements "connected to a more or less definite segment of text [...] keyed to this segment" (ibid., p. 319). In order to appreciate what the notes can tell us about $L a$ independencia's intended functions, we must first identify them and distinguish which are García de Sena's and which are Paine's. Since the translation does not indicate this, the way to distinguish between them is by comparing the translations in La independencia with their corresponding source texts.

García de Sena's translation of Paine's writings has ten

12. In 1811, Connecticut did not have a constitution in the same way that other states and the federal government of the United States did. Before 1818, it had an unwritten constitution (see Horton, 1998). 
notes. ${ }^{13}$ Six are authored by the translator and four by Paine. In other words, six are original and four are translated. Let us first look at the original notes. Five of the six are footnotes. The other original note has its own page and falls under the heading “NOTA DEL TRADUCTOR" [TRANSLATOR'S NOTE]. Perhaps this note is set apart in form from the others because it is by far the longest of the original notes. The others are simple, one-phrase explanations that are not signed by the translator. This one is a two-paragraph explanation of the meaning of the terms "Jury" and "Pares" (in English, peers). There are two other footnotes with lexical explanations. The very first footnote in the translation explains the meaning of the term "Bill." (The other lexical footnote explains the meaning of the Algonquian word "Wampun"-in English, wampum - and is unrelated to political or constitutional concepts.) As to the other footnotes, they contain brief historical or biographical observations that give some context to Paine's writings.

Some conclusions can be drawn from the lexical notes. The translator chose to keep the words bill and jury in English. He translated peers as pares, but felt it necessary to explain its particular usage when discussing a jury of peers. These notes seem to indicate that the concepts of a jury of peers and a legislative bill were foreign to the political process of Spanish America. This is not surprising considering that the Spanish ruled their American empire in a generally autocratic fashion that did not allow for justice with participation of peers and severely limited representative self-government. The translator essentially found no satisfactory equivalent notions in the political language of his target audience.

In essence, what García de Sena did in 1811 through his translations was facilitate the importation of legal rules or legal systems from the United States to Spanish America. When legal rules or systems move from one people or country to another, scholars talk about legal transplants (Watson, 1993, p. 21). When the transplant originates in a country whose system or rules operate in a language other than that of the receiving

13. La independencia has more than ten notes. See, e. g., the note to the Declaration of Independence in the same volume (Bastin, 2010, p. 53). For this paper, however, it will suffice to consider the notes in Paine's writings alone. 
country, translators are involved, often at a financial cost (e. g., Spamann, 2009, pp. 1862-1863). Legal transplants are an example of successful integration of new options into a repertoire. In the case at hand, inasmuch as the Venezuelan constitution and other Spanish American constitutions were influenced by García de Sena's $L a$ independencia, ${ }^{14}$ a successful act of transfer did occur: the translation managed to make the republican, democratic models originally found in the North American constitutions he translated part of the repertoire in the emerging Latin American States.

Regarding the translated footnotes, the first is a documentary note in which Paine reproduces the text of a "pledge and compact [...] prefixed to the constitution" (Paine, 1838, p. 10). The second and third footnotes are personal observations made by Paine. The final footnote is a bibliographical reference.

\section{The Authorship of La independencia}

As mentioned earlier, there is no discernible indication to guide the translation's reader in distinguishing between Paine's notes and García de Sena's notes. In the footnotes, the translator and the original author become one to the reader.

This seemingly unprofessional mingling can be interpreted as an appropriate trait for a work that is unlike anything Paine had actually written. As Grases and Harkness (1953, p. 44) point out: "En el caso de los textos de Paine resalta la labor de selección. García de Sena escogió cuidadosamente las obras que consideró más aplicables a Hispanoamérica, y dentro de ellas, utilizó sólo las partes que tenían aplicaciones generales" [When it comes to Paine's texts, the work of selection stands out. García de Sena carefully chose the works that he felt best applied to Spanish America. From among them, he only picked the portions that were generally applicable]. He was in essence a filter that decided which of Paine's writings were more relevant to justifying the independence of Costa Firme.

In so doing, he became a censor. In his accompanying letter to Ramón, Manuel García de Sena claims that the writings do not contain "una sola palabra contraria á nuestra Religión” [a

14. For a study of the specific influence of García de Sena's translation in Venezuela's first constitution, see Grases (1949, pp. 18-23). 
single word against our Religion]. Yet Paine's writings can hardly be thought of as innocuous to the Catholic Church (ibid., p. 46). García de Sena's solution was simple: when faced with a statement by Paine that could be interpreted as incompatible with Catholic belief, the translator omitted the statement altogether (ibid., pp. 46-47). In this regard, the translator was rather pragmatic: Paine's writings would have lost their efficacy if they were banned or challenged on religious grounds (ibid., p. 47). This is yet another effort to get the power base to back García de Sena's option, particularly since "de nombreux chefs répugnent a s'opposer à L'Église et à la religion” (Bastin, 2010, p. 53).

There may be an element of self-preservation in omitting the passage which could be seen as incompatible with Catholicism. When García de Sena published his translation, he was living in the United States but continued to be involved in his homeland's activities. Soon thereafter he became the representative of Cartagena's revolutionary government ${ }^{15}$ in the United States and interacted personally and by letter with then Secretary of State James Monroe (Grases and Harkness, 1953, pp. 22-26). Eventually, García de Sena returned to South America and became Cartagena's Secretary of War $^{16}$ (ibid., pp. 22-27). He could have lost these opportunities had he been branded as anti-Catholic. If nothing else, his move to censor Paine's comments on religion can be deemed as a politically savvy effort to increase the chances of the translation becoming part of the new repertoire. ${ }^{17}$

15. Cartagena de Indias, commonly known as Cartagena, was an important port city in Costa Firme (now in Colombia). On 11 November 1811, Cartagena declared independence from Spain. Independence would be hard to secure in those turbulent times, and the city fell to Spanish troops in 1815, leading to Bolívar's siege of the city. Permanent independence was achieved only in 1821. It was during 1814 that García de Sena attempted to secure support from Monroe for Cartagena's plight during Spanish efforts to retake the city.

16. Grases and Harkness (1953, p. 27) suggest that García de Sena fled the city when the Spanish retook it and by 1816 had traveled to Jamaica along with other exiles.

17. García de Sena did this elsewhere in La Independencia. In his translation of Virginia's constitution, he added a footnote that runs across three pages (taking up the bulk of the second page) to explain why Virginia barred clergy from holding public office. 
This seems to indicate that García de Sena understood that his option, even if successfully integrated into a new repertoire, could encounter cultural resistance. Even-Zohar (2005, p. 101) points out that the rate of success of integration into the new repertoire depends to a large extent on how much resistance the new options find. Resistance may be passive or active. Passive resistance occurs when people simply ignore the new options (ibid.). Active resistance occurs when people engage in open struggle against the new options (ibid.). Censoring Paine in this way can be interpreted as an effort to reduce the likely resistance to La independencia, both passive (from the population at large) and active (from those in power with strong ties to the Catholic Church). To be fair, García de Sena could not avoid resistance from those who benefitted from the previous repertoire- the Spanish Inquisition banned La independencia after 1815 (Bernstein, 1951, p. 127) - but he did attempt to minimize resistance from those who he hoped would adopt the new options he offered.

Whatever García de Sena's motivations were for editing Paine and complementing his writings with models of implementation (e.g., the U.S. Constitution), there is no question that the paratext lets García de Sena's attitude cast a certain light on $\mathrm{La}$ independencia. Hermans points out that translators indeed "convey attitudes through their translations" (2007, p. 81). In this particular case, the paratext informs the reader of La independencia what that attitude is: endorsement. As indicated above, the paratext informs the reader that the translator believes Paine's ideas are a valid justification for independence but that because they are hard to put into practice, models of implementation are required (and presented in the form of constitutions). However, the endorsement is not as wholehearted as the paratext suggests. By choosing to omit entire sections of Paine's writings and by choosing to censor Paine and conceal that censorship, the translator controls Paine's message. This strategy stresses the point that "[a]11 translating is translating with an attitude" (ibid., p. 85).

What arises from the considerations in the present study is that García de Sena selected the writings he would translate with a very specific political agenda in mind, and when necessary, he censored Paine. Additionally, the translator gave his book a unique structure by adding to the writings of Paine the U.S. Declaration of Independence and seven constitutions. These actions breathed into 
La independencia specific intentions and structures which no single writing by Paine could be said to possess. The intended function of $L a$ independencia - to justify a declaration of independence from Spain by those in Costa Firme and to offer several models of what the new government should look like-was not dictated by Paine. This can be seen when looking at the title, the prefatorial writing, and the notes. In this respect, García de Sena's could well be considered the author of La independencia even more so than Paine.

Of course, such a statement involves a certain degree of subjective judgment, and it is not our intention to draw a bright line between author and translator and then to claim that García de Sena is some sort of hero for transgressing that line. (The relationship between translation and authorship is analyzed, in different contexts, in works such as Levine 1991 and Venutti 2008.) We wish simply to point out García de Sena's strategy when joining the revolution, as reflected in $L a$ independencia's paratext. In his approach to $L a$ independencia, the translator engaged in a number of authorial functions.

\section{Conclusion}

García de Sena lived during a revolutionary period, and he hoped that his translation would help to justify independence and provide constitutional models for the emerging, independent states. However, Omid Azadibougar argues that "translation of concepts into a culture alone cannot signify anything specific nor does it suggest any meaningful impact" (2010, p. 311). Indeed, it must be acknowledged that a translation will not necessarily have an impact on the target culture or political system simply because it exists. Even so, while it is true that the production of options for the repertoire will not in and of itself result in integration (EvenZohar, 2005, p. 87), the producers of those options can engage in many activities to improve the odds of their product making a successful transfer. The paratextual analysis of García de Sena's translation of La independencia shows that such was the case here.

In fact, this particular translation did have a political impact, even if most Latin Americans probably never read it. The book enjoyed a prompt distribution and arose to an influential place in society. Two prominent examples are the River Plate region and Venezuela. In the former, the first constitutional formulations 
of what today are Uruguay and Argentina were influenced by García de Sena's translation (González, 1941, pp.61-64). In Venezuela, the constitution adopted by the First Republic was heavily influenced by García de Sena's translation (Grases, 1949, pp. 14-17). Granted, not everyone was thrilled by the models from the United States (Tanzi, 1979, p. 60). For example, Venezuela's Second Republic was basically a military dictatorship headed by Simón Bolívar, who believed the First Republic had failed because of its federalist model and because it was tolerant of the opposition (Rodríguez O., 1998, p. 121). Even so, the constitutions from the United States were heavily or exclusively influential in the drafting of many Latin American constitutions, including the first national constitutions in Argentina, Chile, and Mexico, charters which drew on García de Sena's translations (Grases and Harkness, 1953, p. 57; Tanzi, 1979, p. 60).

La independencia is, therefore, an important vehicle in the legal transplantation of constitutional notions and structures into Latin America. The translator, Manuel García de Sena, thus became an important figure in the formation of Spanish American states by providing new options for a changing repertoire. Specifically, he provided arguments to justify the independence that would inevitably take place and offered specific models upon which to base the political constitutions of the new nations. During emancipation, some fought with swords to defeat the enemy; Manuel García de Sena used the pen to build the future through translation. His case is a good example, in a world where revolutions are never too far away, of the important role translators can play during revolutionary periods.

\section{References}

Azadibougar, Omid (2010). "Translation Historiography in the Modern World: Modernization and Translation into Persian." Target, 22, 2, pp. 298-329.

Bastin, Georges L. (2004). "Bases para una historia de la traducción en Venezuela" [Bases for a History of Translation in Venezuela]. [http://www.histal.ca/wp-content/uploads/2011/08/Bases-parauna-historia-de-la-traduccion-en-Venezuela.pdf].

Bastin, Georges L. (2006). "Francisco de Miranda, 'precursor' de traducciones" [Francisco de Miranda, 'Forerunner' of Translations]. Boletín de la Academia Nacional de Historia de Venezuela, 354, pp. 167-197. 
Bastin, Georges L. (2010). "Traduction et histoire. Les indispensables paratextes.” In J. C. de Miguel, C. Hernández Sacristán, and J. Pinilla, eds. Enfoques de teoría, traducción y didáctica de la lengua francesa. Hommage à Brigitte Lépinette [Approaches to French Language Theory, Translation, and Teaching: A Tribute to Brigitte Lépinette]. Valencia, Universitat de València, pp. 47-59.

Bastin, Georges L. and Elvia R. Castrillón (2004). "La carta dirigida a los españoles americanos,' una carta que recorrió muchos caminos" ['The Letter to Spanish Americans,' a Letter that Traveled Many Paths]. Hermeneus, 6, pp. 273-290.

Bastin, Georges L. and Álvaro Echeverri (2004). "Traduction et révolution à l'époque de l'indépendance du Venezuela." Meta, 49, 3, pp. 562-575.

Bastin, Georges L. and María G. Iturriza (2008). "La traducción como elemento creador de identidad en la prensa independentista de Venezuela (1808-1822)" [Translation as an Identity-Creating Element in Venezuela's Pro-independence Press (1808-1822)]. TRANS, 12, pp. 81-94.

Bernstein, Harry (1951). "Review of La independencia de la Costa Firme justificada por Thomas Paine treinta anos ha by Manuel García de Sena and Pedro Grases." The Hispanic American Historical Review, 31, 1, pp. 127-128.

De La Guardia, Carmen (2010). "Traductores del republicanismo. Españoles e hispanoamericanos en Estados Unidos (1776-1814)" [Translators of Republicanism: Spanish and Hispanic Americans in the United States (1776-1814)]. Paper presented at the tenth Congreso de Historia Contemporánea. University of Cantabria, Santander, 16-17 September 2010.

Esteves González, Edgar (2007). Batallas de Venezuela 1810-1824 [Battles of Venezuela 1810-1824]. Caracas, Editorial CEC.

Even-Zohar, Itamar (2005). Papers in Culture Research. Tel Aviv, Tel Aviv University.

García De Sena, Manuel (1811). La independencia de la Costa Firme justificada por Thomas Paine treinta años há. Extracto de sus obras traducido del ingles al español por D. Manuel Garcia de Sena [The Independence of Costa Firme as Justified by Thomas Paine Thirty Years Ago. Selections from His Works Translated from English into Spanish by Mr. Manuel García de Sena]. Philadelphia, Thomas and George Palmer.

Genette, Gérard (1997). Paratexts. Thresholds of Interpretation. Trans. Jane E. Lewin. Cambridge, University Press. 
González, Ariosto D. (1941). Las primeras fórmulas constitucionales en los paises del Plata (1810-1813) [The First Constitutional Formulations in the River Plate Countries (1810-1813)]. Montevideo, Claudio García.

Grases, Pedro (1949). "Estudio preliminar" [Preliminary Study]. In Manuel García de Sena, La independencia de la Costa Firme justificada por Thomas Paine treinta años há. Extracto de sus obras traducido del ingles al español por D. Manuel Garcia de Sena [The Independence of Costa Firme as Justified by Thomas Paine Thirty Years Ago. Selections from His Works Translated from English into Spanish by Mr. Manuel García de Sena]. Caracas, Instituto Panamericano de Geografía e Historia, pp. 7-26.

Grases, Pedro and Alberto Harkness (1953). Manuel García de Sena y la independencia de Hispanoamérica [Manuel García de Sena and the Independence of Hispanic America]. Caracas, Secretaría General de la Décima Conferencia Interamericana.

Horton, Wesley W. (1998). "Connecticut Constitutional History 17761988.” Hartford, Connecticut State Library. [http://www.cslib.org/ cts4ch.htm].

Levine, Suzanne J. (1991). The Subversive Scribe. Translating Latin American Fiction. Saint Paul, Greywolf Press.

Paine, Thomas (1792). Common Sense. London, H. D. Symonds.

Paine, Thomas (1795). Dissertation on the First Principles of Government. London, D. I. Eaton.

Paine, Thomas (1838). Dissertations on Government, the Affairs of the Bank, and Paper Money. Philadelphia, Charles Cist.

Pym, Anthony (2010). Translation and Text Transfer: An Essay on the Principles of Intercultural Communication. Tarragona, Intercultural Studies Group.

Racine, Karen. (2002). Francisco de Miranda: A Transatlantic Life in the Age of Revolution. Lanham, Rowman \& Littlefield.

Rodríguez O., Jaime E. (1998). The Independence of Spanish America. Cambridge, University Press.

Spamann, Holger (2009). "Contemporary Legal Transplants. Legal Families and the Diffusion of (Corporate) Law." BYU Law Review, 6, pp. 1813-1878.

Tahir-Gürçağlar, Şehnaz (2002). "What Texts Don't Tell: The Uses of Paratexts in Translation Research." In T. Hermans, ed. Crosscultural Transgressions: Research Models in Translation Studies II. Manchester, St. Jerome, pp. 44-75. 
Tanzi, Héctor J. (1979). Orígenes ideológicos del movimiento emancipador americano [Ideological Sources of the American Independence Movement]. Caracas, Instituto Panamericano de Geografía e Historia.

Venuti, Lawrence (2008). The Translator's Invisibility. A History of Translation. London and New York, Routledge.

Watson, Alan (1993). Legal Transplants. An Approach to Comparative Law. Athens (Ga.), University of Georgia Press.

Gabriel González Núñez

Universitat Rovira i Virgili

The University of Texas Rio Grande Valley One University Blvd., MAIN 1.524

Brownsville, Texas 78520

UNITED STATES

gabriel.gonzaleznunez@utrgv.edu 